\title{
Analisis F-Score untuk Pendeteksian Window Dressing dengan Moderasi Manajemen Laba dan Cash Holding
}

\author{
Niken Savitri Primasari ${ }^{1}$ \\ Fakultas Ekonomi dan Bisnis \\ Universitas Nahdlatul Ulama Surabaya, \\ Indonesia
}

\author{
Endah Tri Wahyuningtyas ${ }^{2}$ \\ Fakultas Ekonomi dan Bisnis \\ Universitas Nahdlatul Ulama Surabaya, \\ Indonesia
}

\begin{abstract}
Surel : niken@unusa.ac.id
\section{ABSTRAK}

Bertujuan untuk mendeteksi laporan keuangan dan pemetaan praktik Window dressing dengan Manajemen Laba dan Cash Holding sebagai moderasi yang akan mengarah pada terjadinya fraudulent financial statement. Sampel penelitian adalah perusahaan non-perbankan yang memiliki nilai DER lebih dari 2.00 dan termasuk dalam indeks kompas 100. Hasil akhir menyimpulkan bahwa seluruh perusahaan pada sampel tidak terindikasi melakukan praktik window dressing dari kinerja keuangan masa lalu mereka sekalipun ada beberapa indikasi Manajemen Laba memoderasi penurunan nilai F-Score yang merepresentasikan Fraudulent Financial Report.
\end{abstract}

Kata Kunci: Cash Holding; Manajemen Laba; Fraudulent Financial Report; Window Dressing.

\section{F-Score Analysis for Window Dressing Detection with Moderated Earnings Management and Cash Holding}

\begin{abstract}
Aims to detect financial statements and possibility of window dressing practices with Earning Management and Cash Holding as moderation that will lead to the fraudulent financial statements. The research samples are non-bank companies with DER value more than 2.00 and included in the kompas 100 index. The final result, indicated no companies conduct window dressing practices of their Performa Past Financial although there are several indicates Manajemen Laba concludes moderation for reduces F-Score that representing the Fraudulent Financial Report.

Keywords: Cash Holding; Earning Management; Fraudulent Financial Report; Window Dressing.
\end{abstract}

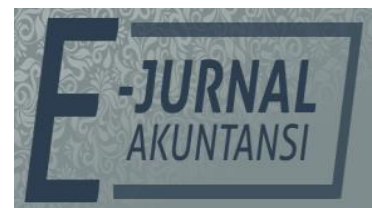

e-ISSN 2302-8556

Vol. 31 No. 5

Denpasar, Mei 2021

Hal. 1189-1200

DOI:

10.24843/EJA.2021.v31.i05.p09

PENGUTIPAN:

Primasari, N.S., \& Wahyuningtyas, E.T. (2021).

Analisis F-Score untuk

Pendeteksian Window

Dressing dengan Moderasi Manajemen Laba dan Cash

Holding. E-Jurnal Akuntansi, 31(5), 1189-1200

RIWAYAT ARTIKEL:

Artikel Masuk:

4 Februari 2021

Artikel Diterima:

24 Mei 2021

Artikel dapat diakses : https://ojs.unud.ac.id/index.php/Akuntansi/index 


\section{PENDAHULUAN}

Semua perusahaan terdaftar di Bursa Efek Indonesia dan memiliki Saham yang diperdagangkan secara publik Bursa saham akan dinyatakan sebagai perusahaan go-publik. Sebagai konsekuansinya, maka perusahaan tersebut memiliki kewajiban untuk menyampaikan berbagai laporan informasi atau berdasarkan fakta material kepada Otoritas Jasa Keuangan (OJK) dan masyarakat, hal ini sesuai dengan peraturan OJK nomor 31 /POJK.04/2015. Adapun laporan tersebut harus memberikan informasi yang transparan, reliable dan akurat.

Seluruh perusahaan tercatat pada sektor-sektor yang terdapat pada BEI tersebut wajib memberikan informasi performa keuangan dan laporan akuntansi baik secara nominal, rasio hingga annual report yang tertuang pada prospektus yang menginformasikan perencanaan strategi bisnis kedepan mereka. Segala informasi tersebut dapat ditransformasikan dalam berbagai bentuk penilaianpenilaian kinerja usaha dengan metode tertentu. Namun perlu diingat, khusus untuk penilaian sektor keuangan dan perdagangan jasa dan investasi, OJK telah menetapkan standarisasi penilaian performa kesehatan pada jenis sektor usaha ini. Berawal dari keadaan inilah, maka penelitian ini akan lebih terkonsentrasi pada perusahaan-perusahaan pada sektor non-keuangan.

Kemudian, berdasar pada temuan yang terjadi di awal triwulan tahun 2019, yakni signal fenomena terjadinya window dressing pada pelaporan keuangan, diawali dengan perusahaan dengan kode saham AISA, GIAA dan JakPro. Fenomena yang terjadi di tahun 2019 inilah yang menarik untuk dilakukan penelitian lebih lanjut mengenai fraudulent financial report. Berdasarkan riset literatur dari review publikasi media massa www.cnnindonesia.com mengenai perusahaan yang tersinyalir melakukan fraudulent dapat digambarkan secara jumlah kejadian pada grafik sebagai berikut.

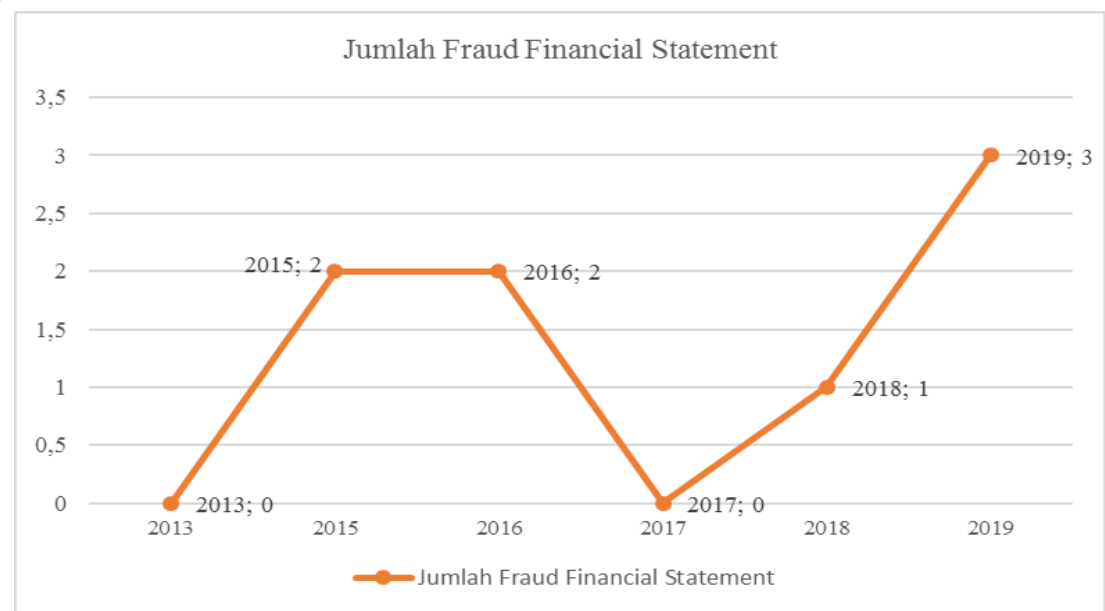

\section{Gambar 1. Jumlah Fraud Financial Statement Tahun 2015 - 2019 Yang Terpublikasi Pada Media Massa}

Sumber: Data Penelitian, 2021

Akuransi, transparansi dan reliability suatu laporan keuangan saat itu terindikasi disalahgunakan karena melakukan beberapa cara skema pencatatan keuangan tertentu. Hal ini dikarenakan investor dan masyarakat kini mampu menginterpretasikan informasi yang dicerminkan oleh rasio-rasio keuangan 
yang terpublikasi di laporan keuangan perusahaan, selanjutnya mereka dapat melakukan interpretasi pada hasil rasio tersebut untuk melihat posisi kekayaan dan kinerja perusahaan. Fenomena ini diperkuat dengan salah satu hasil penelitian psikologi investor di kota Malang tahun 2016 yang menyatakan bahwa Psikologi investor saham di kota Malang rata-rata sudah bisa objektif dalam melakukan analisa saham dari informasi rasio-rasio keuangan yang tersedia di financial reporting (Mulyasari, 2016). Dari sudut pandang akuntansi, pendekatan ini biasanya juga dapat mengesankan pemegang saham dan pemangku kepentingan lainnya dengan memberikan laporan keuangan yang lebih baik daripada situasi sebenarnya (Sohilauw, 2016). Penyalahgunaan laporan keuangan ini biasa terjadi pada akhir tahun dan tercantum dalam prospektus tahunan perusahaan. Hal ini sesuai dengan penelitian yang dilakukan oleh Bestari (2014) dan Utami (2019). Fraudulent financial reporting umumnya terjadi dalam bentuk pemalsuan laporan keuangan sebagai upaya untuk memperoleh keuntungan atau overstatement posisi kekayaan dan kinerja perusahaan (Hosseininia, 2015).

Peningkatan nilai fraud menunjukkan adanya kebutuhan yang mendesak untuk dilakukan penelitian guna menemukan cara yang efektif untuk mendeteksi potensi fraud di perusahaan (Dalnial \& Khairuddin, 2014). Salah satu cara untuk mendeteksi kecurangan dalam laporan keuangan adalah dengan menggunakan rasio keuangan. Adapun rasio-rasio yang relevan dengan posisi kekayaan dan kinerja perusahaan tersebut akan diproksikan oleh perubahan nilai rasio total asset turnover, debt to total asset, net profit margin, earning pershare, price earnings dan harga saham (Zainudin \& Hashim, 2016). Hal ini konsisten dengan penelitian terdahulu tentang pengaruh leverage, profitability, asset composition, liquidity, dan capital turnover terhadap fraudulent financial reporting pada perusahaan Bursa Malaysia (Widyanti, et.al, 2018).

Hasil Performa Past Financial dapat terbaca melalui analisa rasio, dan ini yang mendorong manajemen untuk melakukan overstatement dengan window dressing. Window dressing dilakukan manajemen dengan memberikan penyajian laporan keuangan yang terlihat lebih baik dari keadaan yang sesungguhnya sebagai upaya meningkatkan penampilan kinerja perusahaan tersebut. Dalam hal ini penelitian diawali dengan menggunakan proksi Altman Z-Score sebagai Performa Past Financial reporting. Selanjutnya, penggunaan proksi manajemen laba dan Cash Holding dilakukan untuk mengidentifikasi adanya window dressing yang mengarah pada tindakan fraudulent financial statement yang akan ditunjukkan dengan nilai F-Score model yang diklaim dapat digunakan melakukan pendeteksian salah saji material laporan keuangan dengan tingkat ketepatan 68 persen - 70 persen, Dechow et al., (2012)

Berdasarkan latar belakang tersebut, maka rumusan masalah penelitian ini adalah sebagai berikut, bagaimanakah pengaruh performa past financial berpengaruh terhadap F-Score. Bagaimanakah pengaruh performa past financial terhadap manajemen laba. Bagaimanakah pengaruh past financial terhadap Cash Holding. Apakah dengan tindakan moderasi manajemen laba dan Cash Holding dapat mempengaruhi performa past financial terhadap F-score.

Pemanfaatan penelitian ini diharapkan dapat menyampaikan literasi konseptual, dibidang akuntansi dan manajemen keuangan, yang mungkin dapat 
dikontribusikan untuk suatu organisasi, terutama sebagai salah satu tools forensik akuntansi lembaga keuangan negara maupun forensik akuntansi dan keuangan pasar bursa sebagai salah satu cara meminimalisir tindakan window dressing dan fraudulent financial reporting.

Peningkatan temuan salah saji, baik overstatement ataupun understatement di laporan keuangan, akan dapat menyebabkan kejanggalan pergerakan performa past financial reporting yang akan diproksikan oleh rasio-rasio keuangan. Dikarenakan hal tersebut, maka rasio-rasio keuangan itu dapat dikatakan mampu untuk mensinyalir terjadinya kecurangan dalam laporan keuangan, terutama rasio leverage, rasio profitabilitas, likuiditas dan capital turnover memiliki pengaruh positif pada potensi fraudulent financial reporting (Prajanto \& Pratiwi, 2017), hasil penelitian tersebut juga dipertegaskan oleh penelitian Ansori \& Fajri, (2018) yang menyatakan bahwa rasio analisis terutama rasio leverage memiliki pengaruh positif terhadap tindakan frudulent. Berdasar penelitian tersebut maka rasio-rasio analisis yang merupakan cara untuk melakukan analisis performa perusahaan di tahun sebelumnya akan diuji pengaruhnya terhadap potensi fraudulent financial reporting F-score, maka hipotesis dalam penelitian ini dapat dituliskan sebagai berikut,

$\mathrm{H}_{1}$ : Performa Past Financial Reporting berpengaruh negatif terhadap F-Score.

Pemanipulasian laba atau lebih dikenal manajemen laba disinyalir merupakan salah satu bentuk praktik window dressing laporan keuangan dengan maksud meningkatkan interpretasi nilai rasio kinerja yang baik (Apriliana, 2016) didasari oleh penelitian terdahulu tersebut, maka hipotesis berikutnya dalam penelitian ini adalah, sebagai berikut.

$\mathrm{H}_{2}$ : Performa Past Financial berpengaruh negatif terhadap manajemen laba.

Laporan keuangan yang merupakan dasar untuk menilai kinerja perusahaan dan membantu stakeholder dalam membuat keputusan (Mambraku, 2014). Dikarenakan hal tersebut maka memicu perusahaan dalam melakukan window dressing pada aset lancarnya sebagai usaha untuk meningkatkan kemampuan keuangannya dengan cara melaporkan Cash Holding yang lebih tinggi (Yusiyanti, et al., 2015). Oleh karena itu, hipotesa berikutnya adalah sebagai berikut.

$\mathrm{H}_{3}$ : Performa Past Financial berpengaruh positif terhadap Cash Holding.

Kecurangan laporan keuangan pada umumnya dilakukan dengan cara menyajikan laporan keuangan yang bersifat earning overstated (Sulhani, 2018). Salah satu cara melakukan pendeteksian kecurangan laporan keuangan adalah dengan membandingkan hasil analisis atas laporan keuangan periode saat ini dengan laporan periode sebelumnya (Suranta, 2018). Pengukuran dengan cara FScore merupakan upaya yang dapat digunakan untuk mendeteksi salah saji material dalam laporan keuangan (Sihombing, et al., 2014). Teori agensi yang menjelaskan bahwa adanya konflik antara manajer dan pemegang saham, menunjukkan bahwa adanya keinginan manajemen untuk melakukan Cash Holding di perusahaan agar kinerja perusahaan terlihat baik dimata pemegang saham (Sutrisno, 2017). Selanjutnya, kepemilikan kas atau bisa disebut dengan Cash Holding, merupakan definisi kas lebih yang dimiliki perusahaan. Perlakuan manajemen pada Cash Holding tersebut akan menimbulkan tindakan yang kemudian akan mengarah pada salah saji laporan keuangan (Cicilia, 2019). Dari 
hasil penelitian terdahulu tersebut, maka hipotesa berikutnya di penelitian ini adalah sebagai berikut.

$\mathrm{H}_{4}$ : Moderasi manajemen laba dan Cash Holding berpengaruh positif pada FScore yang mencerminkan terjadinya tindakan window dressing yang mengarah pada fraudulent financial reporting.

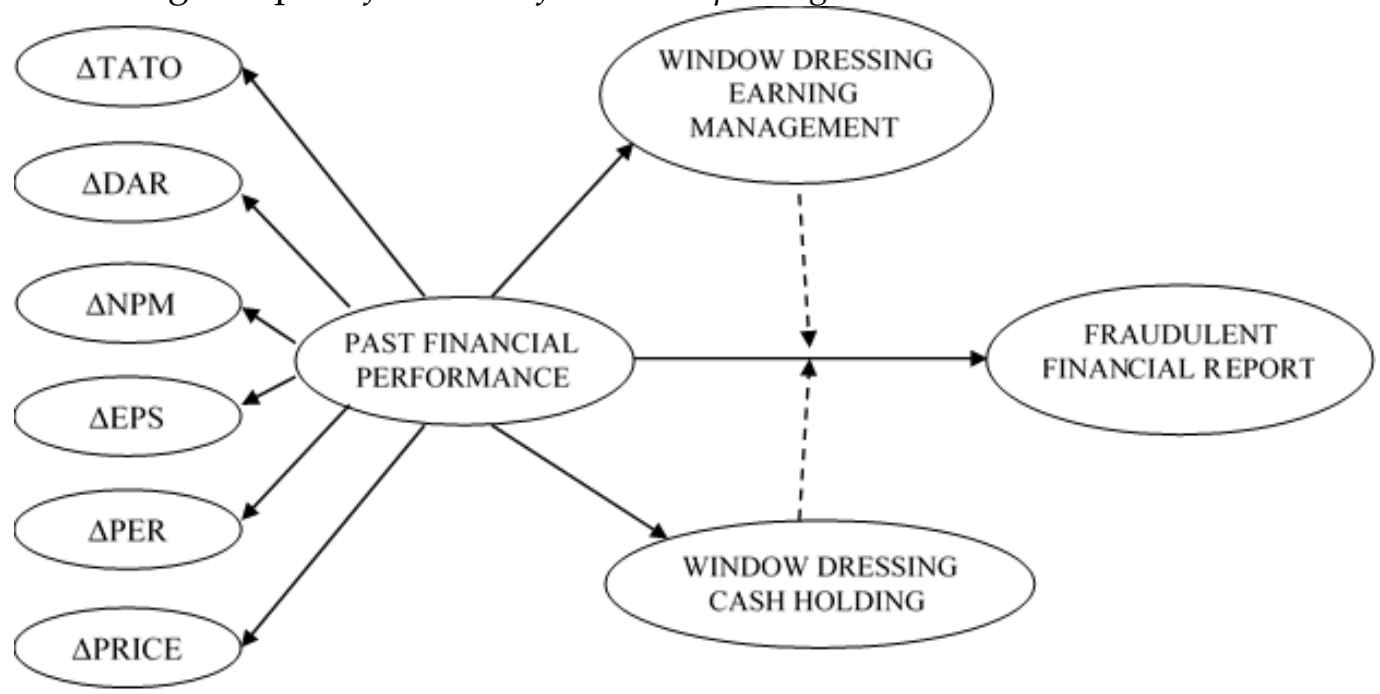

Gambar 1. Model Peneltian

Sumber: Data Penelitian, 2020

\section{METODE PENELITIAN}

Populasi yang digunakan dalam penelitian ini adalah seluruh perusahaan nonkeuangan yang secara konsisten masih tercatat sebagai perusahaan go-publik di Bursa Efek Indonesia selama periode tahun 2015 sampai dengan tahun 2019. Terhitung dapat ditemukan jumlah sampel awal yakni sebanyak 856 data perusahaan tercatat yang selalu konsisten mengeluarkan publikasi laporan keuangan per-triwulan sesuai jadwal yang ditetapkan.

Metode purposive sampling dilakukan pada penelitian ini. Salah satu kriteria yang digunakan yakni perusahaan-perusahaan go publik yang memiliki nilai DER lebih dari 2.00 dan termasuk dalam index kompas 100. Bentuk kriteria pemilihan dengan Debt Equity Ratio (DER) ini disebabkan oleh adanya pemikiran bahwa semakin besar cash flow yang dikeluarkan oleh perusahaan, maka hal ini memicu adanya tindakan Cash Holding. Sebagaimana seperti yang dikatakan oleh Horioka (2014), Arus kas berdampak positif pada perubahan kepemilikan kas (yaitu sensitivitas arus kas yang positif) dan bahwa dampak positif arus kas terhadap perubahan kepemilikan tunai lebih besar dan lebih signifikan dalam kasus perusahaan yang lebih kecil dan mungkin lebih terkendala.

Pernyataan tersebut memberi arti bila arus kas memiliki dampak positif terhadap perubahan dalam Cash Holdings (yaitu sensitivitas arus kas dari kas adalah positif) dan bahwa pengaruh positif arus kas pada perubahan cash holdings lebih besar dan lebih signifikan dalam kasus perusahaan yang memiliki cash flow lebih kecil dan mungkin perusahaan tersebut memiliki jumlah cash holding yang kecil. 
Dari penerapan kriteria tersebut didapatkan jumlah sampel terpilih di dalam penelitian ini adalah sebanyak 360 sampel. Penelitian ini dilakukan dalam kondisi lingkungan yang sesungguhnya dengan data analisis perusahaan publik yang diperoleh dari data sekunder yang bersifat transparan. Data sekunder terdapat pada web data perpustakaan Bursa Efek Indonesia (TICMI) dan IDX. Laporan keuangan perusahaan yang akan digunakan berasal dari laporan keuangan pada triwulan ketiga dan laporan keuangan tahunan. Dalam upaya memperoleh hasil yang optimal atas penelitian, diawali tindakan klasifikasi kondisi keuangan perusahaan dengan metode Altman Z-Score.

Setelah pengujian asumsi klasik dilakukan, analisis regresi linier berganda akan dilakukan untuk menguji pengaruh antara variabel independen dan dependen, yang dilanjutkan dengan pengujian moderated regression analysis (MRA).

Hasil tersebut akan memberikan bukti pengujian hipotesis, untuk mengetahui pengaruh perolehan nilai akseptasi (signifikan) variabel independen terhadap variabel dependen dan perlakuan variabel independen dengan moderasi terhadap variabel dependen. Adapun variabel independen yang diteliti dari performa past financial yang berasal dari laporan keuangan triwulan ketiga yang diproksikan dengan perubahan nilai rasio total asset turnover, debt to total asset, net profit margin, earning pershare, price earning ratio dan harga saham, dimana seluruh nilai tersebut merupakan pembentuk nilai dari Altman Z-Score yang merupakan proksi dari variabel independen Performa Past Financial pada penelitian ini dan dengan dua variabel moderasi, yakni window dressing dengan tindakan manajemen laba dan window dressing dengan tindakan Cash Holding. Selanjutnya, fraudulent financial reporting sebagai variabel dependen penelitian yang diproksikan dengan nilai F-Score sebagai salah satu alat mendeteksi kecurangan dalam laporan keuangan. F-Score terdiri dari dua komponen, yaitu kualitas akrual dan kinerja keuangan. Dalam penelitian ini F-Score atau Fraud Score yang digunakan untuk mengukur tingkat risiko kecurangan pelaporan keuangan di dalam perusahaan (Agusputri dan Hanifah, 2019).

\section{HASIL DAN PEMBAHASAN}

Pada pengujian model 1 yakni menemukan pengaruh dari performa past financial perusahaan dengan kemungkinan terjadinya fraudulent financial report ini dapat diketahui dari tabel uji $\mathrm{F}$ dan $\mathrm{t}$ sebagai berikut,

Tabel 1. Nilai Uji F dan t-test Variabel Z-Score terhadap F-Score

\begin{tabular}{lcc}
\hline \multirow{2}{*}{ Output } & \multicolumn{2}{c}{ Regresi ZSC to FSC } \\
\cline { 2 - 3 } & F-test & t-test \\
\hline $\mathrm{n}$ & 360 & 360 \\
Significant & $0,000^{\mathrm{b}}$ & 0,000 \\
Value & 52,219 & $-7,226$ \\
\hline
\end{tabular}

Sumber: Data Penelitian, 2020

Past Financial Report yang dilihat dengan nilai Z-Score atau ZSC dan Fraudulent Financial Report yang diproksikan dengan F-Score atau FSC memiliki tingkat hasil uji fit model yang layak, karena memiliki nilai signifikasi uji $\mathrm{F}$ senilai 0,000 (lebih kecil dari $\alpha=0,05$ ) pada nilai value 52,219 yang memberi arti bahwa nilai Z-Score memiliki pengaruh langsung pada nilai F-Score. 
Selanjutnya berdasarkan nilai uji-t sebesar -7,226 dengan nilai signifikan 0,000, lebih kecil dari nilai $a=0,05$, menunjukkan antara Performa Past Financialdengan Fraudulent Financial Report yang memiliki hubungan signifikasi negatif (bertolak belakang) yang berarti hipotesis 2 diterima, yakni Performa Past Financial berpengaruh negatif terhadap Fraudulent Financial Reporting.

Dari hasil uji statistik F-test dan t-test tersebut dapat disimpulkan semakin kecil nilai Financial Past Performance, maka semakin tinggi tingkat F-Score yang terjadi. Semakin tingginya tingkat F-Score menandakan semakin tinggi pula kemungkinan terjadinya Fraudulent Financial Report. Hubungan negatif antara ZScore dengan F-Score ini dapat dikatakan absolut terjadi, mengingat secara teoritis perusahaan yang terkena distress dan tersinyalir bangkrut adalah perusahaan yang memiliki nilai Z Score (altman) lebih kecil dari 1,81. Sebaliknya dengan F-Score. Semakin tinggi nilai F Score, yakni lebih dari 1, menunjukkan semakin tinggi pula potensi terjadinya Financial Fradulent Financial Report karena perusahaan sedang berada pada tingkat resiko yang sangat tinggi.

Tabel 2. Nilai Beta dan Konstanta Hasil t-test Variabel Z-Score terhadap FScore

\begin{tabular}{lcc}
\hline \multirow{2}{*}{ Output } & \multicolumn{2}{c}{ Regresi ZSC to FSC } \\
\cline { 2 - 3 } $\mathrm{n}$ & Beta & t-test \\
Constant & 360 & 360 \\
Z-Score & 4,636 & 26,380 \\
& $-1,960$ & $-7,226$
\end{tabular}

Sumber: Data Penelitian, 2020

Penjelasan yang dapat diberikan berkaitan hasil nilai beta dan konstanta dari hasil t-test adalah, (1) Apabila nilai Z-Score adalah nol maka, F-Score akan mengalami kenaikan absolut sebesar 4,636. (2) Nilai koefisien yang ditunjukkan dengan nilai beta Z-Score sebesar -1,960 mengindikasikan bahwa apabila terjadi penambahan nilai Z-Score sebesar 1 persen maka akan dapat mengurangi nilai absolut konstanta sebesar 4,646, dan nilai F-Score akan menurun. Sehingga dapat dikatakan bahwa hipotesis 2 diterima, yakni Performa Past Financial berpengaruh negatif terhadap Fraudulent Financial Reporting

Hal ini membuktikan semakin tinggi nilai Z-Score, terutama nilai Z-Score lebih dari 2,67 maka, semakin baik pula nilai financial past performance suatu perusahaan (Laksito, 2015). Semakin baik nilai performance suatu perusahaan, semakin kecil pula tingkat perusahaan melakukan tindakan fraudulent financial report. Oleh kerena itu, dapat diartikan bahwa tingkat kinerja akan mendorong manajemen perusahaan untuk melaksanakan kewajiban-kewajibannya dan menampilkan Kinerja perusahaan harus sebaik mungkin untuk mencapai tingkat kinerja yang baik. Keadaan ini berdampak kecil terhadap risiko karena manajemen perusahaan menerapkan kinerja keuangan yang prudent sehingga mengurangi kemungkinan terjadinya kecurangan laporan keuangan (Kurniawansyah, 2018).

Nilai uji F antara Nilai Z-Score atau ZSC dan Manajemen Laba atau ERM memiliki tingkat hasil uji fit model yang layak, karena memiliki nilai signifikan uji $\mathrm{F}$ sebesar 0,000 (lebih kecil dari $a=0,05$ ) dengan nilai value 77,626 yang memberi arti bahwa nilai Z-Score memiliki pengaruh langsung pada nilai F-Score. 
Tabel 3. Nilai Uji F dan t-test Variabel Z-Score terhadap Manajemen Laba

\begin{tabular}{lcc}
\hline \multirow{2}{*}{ Output } & \multicolumn{2}{c}{ Regresi ZSC to ERM } \\
\cline { 2 - 3 } & F-test & t-test \\
\hline $\mathrm{n}$ & 360 & 360 \\
Significant & $0,000^{\mathrm{b}}$ & 0,000 \\
Value & 77,626 & $-8,811$ \\
\hline
\end{tabular}

Sumber: Data Penelitian, 2020

Berikutnya dengan nilai uji-t sebesar minus 8,811 dengan nilai signifikan 0,000, lebih kecil dari nilai $\alpha=0,05$, menunjukkan bahwa Performa Past Financial memiliki hubungan yang signifikan negatif (bertolak belakang) dengan Manajemen Laba. Dengan kondisi ini maka dapat dikatakan jika hipotesis 2 diterima, Performa Past Financial berpengaruh negatif terhadap Manajemen Laba.

Dari hasil tersebut dapat disimpulkan ketika nilai financial past performance suatu perusahaan mengalami peningkatan signifikan, maka akan menurunkan nilai manajemen labanya. Semakin baik performa suatu perusahaan, maka perusahaan cenderung tidak melakukan tindakan window dressing dengan cara manajemen laba.

Tabel 4. Nilai Beta dan Konstanta Hasil t-test Variabel Z-Score terhadap ERM

\begin{tabular}{lcc}
\hline \multirow{2}{*}{ Output } & \multicolumn{2}{c}{ Regresi ZSC to ERM } \\
\cline { 2 - 3 } & Beta & t-test \\
\hline $\mathrm{n}$ & 360 & 360 \\
Constant & 0,008 & 53,163 \\
Z-Score & $-0,002$ & $-8,811$ \\
\hline
\end{tabular}

Sumber: Data Penelitian, 2020

Nilai beta hasil t-test Z-Score terhadap ERM memberi indikasi, (1) Apabila nilai Z-Score adalah nol maka, perusahaan cenderung bernilai absolut sebesar 0,008. Nilai ERM yang kecil ini menandakan bahwa sebenarnya tindakan Manajemen Laba bukanlah suatu indikasi perlakuan window dressing, namun lebih kepada tindakan manajemen untuk melakukan kontrol pada pendapatan perusahaan, asal tentunya dilakukan dengan koridor yang benar. Hal ini pun sesuai dengan yang dikatakan oleh Kurniawansyah, (2018), bahwa Manajemen laba tidak selalu berarti manipulasi yang dilakukan dengan mengungkit laba sehingga menyajikan laba yang lebih tinggi. Manajemen laba adalah berkaitan dengan penjagaan harapan bahwa periode mendatang nilai perform akan lebih baik. Nilai koefisien yang ditunjukkan dengan nilai beta Z-Score 8,811 mengindikasikan bila nilai Z-Score bertambah 1 persen akan mengurangi nilai absolut konstanta sebesar 0,002, sehingga menurunkan nilai Manajemen Laba.

Tabel 5. Nilai Uji F dan t-test Variabel Z-Score terhadap Cash Holding

\begin{tabular}{lcc}
\hline \multirow{2}{*}{ Output } & \multicolumn{2}{c}{ Regresi ZSC to CSH } \\
\cline { 2 - 3 } & F-test & t-test \\
\hline $\mathrm{n}$ & 360 & 360 \\
Significant & $0,322^{\mathrm{b}}$ & 0,322 \\
Value & 0,985 & $-0,992$ \\
\hline
\end{tabular}

Sumber: Data Penelitian, 2020 
Data dalam Tabel 5, tersebut menunjukkan bahwa pengujian antara Z-Score dengan Cash Holding perusahaan (CSH) ditolak, karena tidak lolos uji fit model, karena nilai signifikan dari uji F ZSC terhadap CSH bernilai lebih dari 0,05. Hal inipun terindikasi pula dari hasil $t$-test yang tidak signifikan. Sehingga dapat dikatakan hipotesis nol diterima, yang menyebutkan antara Performa Past Financial dengan Cash Holding tidak berpengaruh.

Tabel 6 . Uji F Moderasi Manajemen Laba dan Cash Holding untuk Pengaruh Variabel Z-Score terhadap Fraudulent Financial Report

\begin{tabular}{lc}
\hline \multirow{2}{*}{ Output } & MRA ZSC to FSC with ZEM and ZCH \\
\cline { 2 - 2 } & F-test \\
\hline Significant & 360 \\
Value & $0,000 \mathrm{~b}$ \\
Sur & 15,125 \\
\hline
\end{tabular}

Sumber: Data Penelitian, 2020

Data dalam Tabel 6, menunjukkan bahwa secara hubungan bersama-sama (simultan) antara ZSC dengan ERM dan CSH dan moderasi ERM (ZEM) dan moderasi $\mathrm{CSH}(\mathrm{ZCH})$, dapat mencerminkan nilai F-Score atau mempengaruhi secara langsung nilai F-Score yang merupakan proksi dari Fraudulent Financial Report. Hal ini membuktikan pula bahwa formulasi ZSC dengan moderasi ZEM dan $\mathrm{ZCH}$, memiliki tingkat hasil uji fit model yang layak, karena memiliki nilai signifikan uji F sebesar 0,000 (lebih kecil dari $\alpha=0,05$ ) dengan nilai value 15,125.

Tabel 7. Nilai Beta dan Konstanta Hasil t-test Variabel ZSC terhadap FSC dengan variabel moderasi ZEM dan $\mathrm{ZCH}$

\begin{tabular}{lcc}
\hline \multirow{2}{*}{ Output } & \multicolumn{2}{c}{ MRA ZSC to FSC with ZEM and ZCH } \\
\cline { 2 - 3 } & Beta & Significant \\
\hline $\mathrm{n}$ & 360 & 0,000 \\
Constant & 4,921 & 53,163 \\
Z-Score & 0,833 & 0,414 \\
Manajemen Laba & 13,302 & 0,871 \\
Cash Hold & $-5,016$ & 0,609 \\
Moderasi EM & $-602,241$ & 0,001 \\
Moderasi CH & 21,188 & 0,447 \\
\hline
\end{tabular}

Sumber: Data Penelitian, 2020

Dari hasil MRA Z-Score terhadap nilai F-Score dengan memasukkan variabel ERM dan CSH sebagai moderasi, didapatkan hasil bahwa hanya tindakan Manajemen Labayang mampu memoderasi terbentuknya nilai F-Score, dengan nilai beta $-602,241$ dan nilai significant 0,001. Nilai beta tersebut memberikan tanda bahwa semakin besar nilai Manajemen Laba, maka semakin memperkecil nilai F-Score yang terbentuk. Hal ini membuktikan secara statistik, bahwa tindakan Manajemen Laba pada kinerja keuangan masa lalu (PFP) tidak merupakan indikasi terjadinya fraudulent. Malah sebaliknya, semakin besar tindakan manajemen untuk melakukan kontrol laba mereka, maka perusahaan tersebut akan terhindar dari tindakan fraudulent financial reporting yang disebabkan oleh keinginan dari pihak-pihak tertentu untuk melakukan make up (window dressing) pada laporan keuangannya.

Ini menjelaskan bahwa manajemen laba dilakukan sebagai tindakan para manajer perusahaan untuk memastikan bahwa kinerja perusahaan selalu memperoleh hasil keuangan maksimal dengan minimal targeting yakni performa 
keuangan di tahun sebelumnya. Ini menunjukkan perusahaan bertanggungjawab atas modal dari sebagian investornya dengan selalu memberikan sinyal yang baik bagi investor dengan selalu berupaya menggunakan targeting pendapatan sebagai dasar peningkatan kinerja perusahaan. Namun, bila dilihat secara simultan, uji MRA dengan moderasi ini tidak berpengaruh signifikan, karena hanya Manajemen Laba yang mampu memoderasi nilai Z-Score terhadap F-Score dengan hubungan terbalik. Dengan demikian maka dapat dikatakan tidak terjadi tindakan window dressing pada seluruh Laporan keuangan yang terdaftar di bursa efek Indonesia, terutama untuk perusahaan-perusahaan yang menjadi sampel dalam penelitian ini.

\section{SIMPULAN}

Penelitian ini menunjukkan bahwa secara (1) Past Financial Report yang diproksikan dengan nilai Z-Score atau ZSC dan Fraudulent Financial Report yang diproksikan dengan F-Score atau FSC memiliki pengaruh langsung pada nilai FScore secara negatif. Sehingga dapat dikatakan bahwa hipotesis 1 diterima, yakni Performa Past Financial berpengaruh negatif terhadap Fraudulent Financial Reporting. Dengan nilai uji-t sebesar minus 8,811 dengan nilai signifikan 0,000, lebih kecil dari nilai $a=0,05$, menunjukkan bahwa Performa Past Financial memiliki hubungan yang signifikan negatif (bertolak belakang) dengan Manajemen Laba. Dengan kondisi ini maka dapat dikatakan jika hipotesis 2 diterima, Performa Past Financial berpengaruh negatif terhadap Manajemen Laba. Pengujian secara parsial antara Z-Score dengan Cash Holding perusahaan $(\mathrm{CSH})$ memiliki nilai signifikan lebih dari 0,05 berikut pula dengan hasil t-test yang tidak signifikan. Sehingga dapat dikatakan hipotesis nol diterima, yakni Performa Past Financial dengan Cash Holding tidak memiliki hubungan dan tidak berpengaruh. Uji MRA dengan moderasi ZEM dan ZCH tidak berpengaruh signifikan, karena hanya Manajemen Laba yang mampu memoderasi nilai $Z$ Score terhadap F-Score dengan hubungan terbalik.

Dengan demikian maka dapat dikatakan tidak terjadi tindakan window dressing pada seluruh laporan keuangan yang tercatat di Bursa Efek Indonesia, terutama untuk perusahaan-perusahaan yang menjadi sampel pada penelitian ini. Sehingga dapat disimpulkan bahwa perusahaan sektor non-perbankan yang terdaftar di BEI pada 2015-2019 tidak diindikasikan melakukan praktik window dressing dari kinerja keuangan masa lalu mereka meskipun ada beberapa alasan manajemen pendapatan menyimpulkan sebagai moderasi untuk F-Score. Ini menjelaskan bahwa manajemen laba dilakukan sebagai tindakan untuk memastikan kinerja perusahaan keuangan dan target mereka selalu memiliki sinyal yang baik bagi investor mereka.

Apresiasi yang terhingga bagi Kementerian Riset dan Teknologi/Badan Riset dan Inovasi Nasional Indonesia yang telah memberikan kesempatan kepada saya dengan program dana penuh bagi peneliti Indonesia, berdasarkan SK No.8/E1/KPT/2020 dan kontrak LPPM UNUSA No 297.30/UNUSA/AdmLPPM/IV/2020. Terima kasih kepada tim LPPM Universitas Nahdlatul Ulama Surabaya yang telah mendukung penuh seluruh proses publikasi penelitian ini. 


\section{REFERENSI}

Agusputri, Hanifah \& Sofie, Sofie. (2019). Faktor-faktor yang Berpengaruh terhadap Fraudulent Financial Reporting dengan Menggunakan Analisi Fraud Pentagon. Jurnal Informasi, Perpajakan, Akuntansi dan Keuangan Publik. 14. 105. 10.25105/jipak.v14i2.5049.

Ansori, Muslim \& Fajri, Salmu. (2018). Pendeteksian Kecurangan Laporan Keuangan Menggunakan Rasio Keuangan dengan Umur Perusahaan dan Ukuran Perusahaan sebagai Variabel Kontrol. Journal Of Applied Managerial Accounting. 2. 141-159. 10.30871/jama.v2i2.805.

Apriliana, Shindy Virgin. (2016). Analisis Window Dressing pada Perusahaan Badan Usaha Milik Negara yang Terdaftar di Bursa Efek Indonesia Periode 2012-2014. STIE Perbanas.

Bestari, Widya Ayu. (2014). Analisis Window Dressing pada Perusahaan Sektor Industri Barang Konsumsi yang Terdaftar di Bursa Efek Indonesia Periode 20102013. Program Studi Akuntansi, Fakultas Ekonomi Universitas Maritim Raja Ali Haji. Tanjungpinang.

Cicilia, Orlin. (2019). Pengaruh Financial Clasification, Financial Indicators dan Corporate Performance terhadap Manajemen Laba. Jurnal Informasi, Perpajakan, Akuntansi dan Keuangan Publik. 13. 55. 10.25105/jipak.v13i1.5008.

Dalnial, H., Kamaluddin, A., Sanusi, Z. M., \& Khairuddin, K. S. (2014). Detecting Fraudulent Financial Reporting through Financial Statement Analysis, 2(1), 17-22.

Dechow, P. M, Hutton, A. P, Kim, J H, and Sloan, R. G. (2012) Detecting Manajemen Laba: A New Approach. Journal of Accounting Research, Vol. 50, Ed. 2, Hal. 275-334

Horioka, Charles \& Terada-Hagiwara, Akiko. (2014) Corporate Cash Holding in Asia. Asian Economic Journal. 28. 10.1111/asej.12039.

Hosseininia, Somayyeh. (2015). Financial ratios between fraudulent and nonfraudulent firms: Evidence from Tehran Stock Exchange. Journal of Accounting and Taxation. 7. 38-44. 10.5897/JAT2014.0166..

Kurniawansyah, Deddy. (2018). Apakah Manajemen Laba Termasuk Kecurangan ?: Analisis Literatur. Jurnal Riset Akuntansi dan Bisnis Universitas Airlangga 3(1), 2018, p.341-356, tahun 2018. 10.31093/jraba.v3i1.97

Laksito, Hanifa. (2015). Pengaruh Fraud Indicators Terhadap Fraudulent Financial Statement: Studi Empiris pada Perusahaan yang Listed di Bursa Efek Indonesia (BEI) tahun 2008-2013. Diponegoro Journal of Accounting 04, (04), Tahun 2015, Halaman 1-15

Mambraku, Milka Erika. (2014). Pengaruh Cash Holding dan Struktur Kepemilikan Manajerial Terhadap Income Smoothing. Skripsi. Fakultas Ekonomika dan Bisnis Universitas Diponegoro

Mulyasari, W. (2016). Disclosure Dan Psikologi Investor. Jurnal Riset Akuntansi Terpadu, 9(1).

Prajanto, Agung \& Pratiwi, Ririh. (2017). The Impact of Corporate Cultures and Financial Ratios on The Fraudulent Financial Reporting. Jurnal Dinamika Akuntansi. 8. 39. 10.15294/jda.v8i1.9120. 
Sihombing, Kennedy Samuel dan Rahardjo, Shiddiq Nur. (2014). Analisis Fraud Diamond dalam Mendeteksi Financial Statement Fraud: Studi Empiris pada Perusahaan Manufaktur yang Terdaftar di Bursa Efek Indonesia (BEI) Tahun 2010- 2012. Diponegoro Journal of Accounting Vol. 03 No. 02. ISSN (Online): 2337-3806.

Sohilauw, Muhammad. (2016). Window Dressing sebagai Manifestasi Ekonomi Kapitalis (Analisis Semiotika) 10.13140/RG.2.2.16758.65602.

Sondakh, Mandagie. (2014). Analisis Potensi Kebangkrutan dengan Menggunakan Metode Altman Z-Score, Springate dan Zmijewski pada Industri Perdagangan Ritel yang Terdaftar di BEI Periode 2009-2013. Jurnal EMBA 2.4. doi.org/10.35794/emba.v2i4.6336

Sulhani, Alif Hidayatullah, (2018). Pengaruh Manipulasi Laporan Keuangan dan Karakteristik Chief Financial Officer terhadap Ketepatwaktuan Pelaporan Keuangan dengan Kualitas Audit Sebagai Variabel Pemoderasi. Jurnal Dinamika Akuntansi dan Bisnis Vol. 5(2), 2018, dx.doi.org/10.24815/jdab.v5i2.10872.

Suranta, Perdana. (2017). Analisis Kinerja Keuangan Pemerintah Daerah: Studi Komparasi Propinsi Jawa Tengah dan Kalimantan Selatan. p-ISSN: 2088768X. e-ISSN: 2540-9646. DOI 10.24964/ja.v5i2.284. http://jurnalfe.ustjogja.ac.id/index.php/akuntansi/article/view/284.

Sutrisno, Bambang. (2017). Hubungan Cash Holding dan Nilai Perusahaan di Indonesia. Jurnal Dinamika Akuntansi dan Bisnis. 4.45. 10.24815/jdab.v4i1.6340.

Utami, Yuvita. (2019). Fraud Pentagon Dalam Mendeteksi Risiko Kecurangan Laporan Keuangan Pada Perusahan Manufaktur Tahun 2016-2018. 10.25105/semnas.v0i0.5845

Widyanti, Tyas \& Amin, Muhammad. (2018). Pengaruh Rasio Keuangan Terhadap Fraudulent Financial Reporting: Survei Perusahaan Barang Konsumsi Yang Terdaftar di Bursa Efek Indonesia Tahun 2014-2016. Assets: Jurnal Akuntansi dan Pendidikan. 7. 72. 10.25273/jap.v7i1.2360.

Yusiyanti, Hindun, Negina Kencono dan Eliada Herwiyanti. (2015). Analisis Window Dressing Perusahaan Go Public Sektor Infrastruktur, Utilitas, dan Transportasi di Indonesia. Telaah Manajemen Fakultas Ekonomi dan Bisnis Universitas Jenderal Soedirman. Vol. 10, No. 2.

Zainudin, E. F., \& Hashim, H. A. (2016). Detecting fraudulent financial reporting using financial ratio. Journal of Financial Reporting and Accounting, 14(2), 266278. 